\title{
Exogenous hydrogen sulfide promotes hepatocellular carcinoma cell growth by activating the STAT3-COX-2 signaling pathway
}

\author{
YULAN ZHEN $^{1 *}$, QIAOMEI WU ${ }^{2 *}$, YIQIAN DING ${ }^{3}$, WEI ZHANG ${ }^{4}$, YUANSHENG ZHAI $^{4}$, XIAOXIONG LIN $^{4}$, \\ YUNXIA WENG ${ }^{4}$, RUIXIAN GUO ${ }^{5}$, YING ZHANG ${ }^{6}$, JIANQIANG FENG ${ }^{5}$, YIYAN LEI ${ }^{7}$ and JINGFU CHEN ${ }^{8}$ \\ ${ }^{1}$ Department of Oncology, The Third People's Hospital of Dongguan Dongguan City, Guangdong 523326; \\ ${ }^{2}$ Department of Anesthesiology, Oral Subsidiary Sun Yat-Sen University Hospital, Sun Yat-sen University, Guangzhou, \\ Guangdong 510700; ${ }^{3}$ Grade 2013, Medical Imaging, The First School of Clinical Medicine, Southern Medical University, \\ Guangzhou, Guangdong 510000; ${ }^{4}$ Department of Cardiovasology and Cardiac Care Unit, Huangpu Division of \\ The First Affiliated Hospital, Guangzhou, Guangdong 510080; ${ }^{5}$ Department of Physiology, Zhongshan School of \\ Medicine, Sun Yat-sen University, Guangzhou, Guangdong 510700; ${ }^{6}$ Department of Oncology, Affiliated Hospital,
} Guangdong Medical College, Zhanjiang, Guangdong 524001; ${ }^{7}$ Department of Thoracic Surgery, The First Affiliated Hospital,

Sun Yat-Sen University, Guangzhou, Guangdong 510080; ${ }^{8}$ Department of Cardiovascular Medicine and Dongguan

Cardiovascular Institute, The Third People's Hospital of Dongguan City, Dongguan, Guangdong 523326, P.R. China

Received November 28, 2015; Accepted April 21, 2017

DOI: $10.3892 / \mathrm{ol} .2018 .8154$

\begin{abstract}
The effects of hydrogen sulfide $\left(\mathrm{H}_{2} \mathrm{~S}\right)$ on cancer are controversial. Our group previously demonstrated that exogenous $\mathrm{H}_{2} \mathrm{~S}$ promotes the development of cancer via amplifying the activation of the nuclear factor- $\kappa \mathrm{B}$ signaling pathway in hepatocellular carcinoma (HCC) cells (PLC/PRF/5). The present study aimed to further investigate the hypothesis that exogenous $\mathrm{H}_{2} \mathrm{~S}$ promotes $\mathrm{PLC} / \mathrm{PRF} / 5$ cell proliferation and migration, and inhibits apoptosis by activating the signal transducer and activator of transcription 3 (STAT3)-cyclooxygenase-2 (COX-2) signaling pathway. PLC/PRF/5 cells were treated with 500 $\mu \mathrm{mol} / 1 \mathrm{NaHS}$ (a donor of $\mathrm{H}_{2} \mathrm{~S}$ ) for $24 \mathrm{~h}$. The expression levels of phosphorylated (p)-STAT3, STAT3, cleaved caspase-3 and COX-2 were measured by western blot assay. Cell viability was detected by Cell Counting kit- 8 assay. Apoptotic cells were observed by Hoechst 33258 staining. The expression of STAT3 and COX-2 messenger RNA (mRNA) was detected by semiquantitative reverse transcription-polymerase chain
\end{abstract}

Correspondence to: Dr Yiyan Lei, Department of Thoracic Surgery, The First Affiliated Hospital, Sun Yat-Sen University, 58 Zhongshan 2nd Road, Guangzhou, Guangdong 510080, P.R. China

E-mail: leiyy@yahoo.com.cn

Dr Jingfu Chen, Department of Cardiovascular Medicine and Dongguan Cardiovascular Institute, The Third People's Hospital of Dongguan City, 1 Xiangiong Road, Dongguan, Guangdong 523326, P.R. China

E-mail: chenjf-sums@hotmail.com

*Contributed equally

Key words: hydrogen sulfide, growth, STAT3, PLC/PRF/5 cells, COX-2 reaction. The production of vascular endothelial growth factor (VEGF) was evaluated by ELISA. The results indicated that treatment of PLC/PRF/5 cells with $500 \mu \mathrm{mol} / 1 \mathrm{NaHS}$ for $24 \mathrm{~h}$ markedly increased the expression levels of p-STAT3 and STAT3 mRNA, leading to COX-2 and COX-2 mRNA overexpression, VEGF induction, decreased cleaved caspase-3 production, increased cell viability and migration, and decreased number of apoptotic cells. However, co-treatment of PLC/PRF/5 cells with $500 \mu \mathrm{mol} / 1 \mathrm{NaHS}$ and $30 \mu \mathrm{mol} / 1$ AG490 (an inhibitor of STAT3) or $20 \mu \mathrm{mol} / 1 \mathrm{NS}-398$ (an inhibitor of COX-2) for $24 \mathrm{~h}$ significantly reverted the effects induced by NaHS. Furthermore, co-treatment of PLC/PRF/5 cells with $500 \mu \mathrm{mol} / 1 \mathrm{NaHS}$ and $30 \mu \mathrm{mol} / 1$ AG490 markedly decreased the NaHS-induced increase in the expression level of COX-2. By contrast, co-treatment of PLC/PRF/5 cells with $500 \mu \mathrm{mol} / 1 \mathrm{NaHS}$ and $20 \mu \mathrm{mol} / 1 \mathrm{NS}-398$ inhibited the NaHS-induced increase in the expression level of p-STAT3. In conclusion, the findings of the present study provide evidence that the STAT3-COX-2 signaling pathway is involved in NaHS-induced cell proliferation, migration, angiogenesis and anti-apoptosis in PLC/PRF/5 cells, and suggest that the positive feedback between STAT3 and COX-2 may serve a crucial role in hepatocellular carcinoma carcinogenesis.

\section{Introduction}

Hepatocellular carcinoma (HCC) is the most frequent subtype of primary liver cancer (PLC), which is the third leading cause of cancer-associated mortality worldwide and results from poor prognosis (1-3). A variety of methods are applied in the treatment of HCC, including surgery, local treatment and liver transplantation. However, $<20 \%$ of patients are eligible for effective therapies (4). Furthermore, the 5-year survival rate worldwide of $\mathrm{HCC}$ is still $<5 \%$, as a result of its high rate of recurrence and metastasis (5). HCC tumorigenesis is a complex 
multistep process that is closely associated with multiple signaling pathways and genes, and these factors can affect cell survival, proliferation, invasion and metastasis (6,7). The role of hepatitis $\mathrm{B}$ virus (HBV) or hepatitis $\mathrm{C}$ virus infection has been extensively investigated and considered as one of the reasons in the pathogenesis of $\mathrm{HCC}(8,9)$. Of note, increasing evidences demonstrate that additional non-viral signaling pathways are involved in the progression of the disease (10). Thus, to explore the effects of these signaling pathways on cell growth and invasion is conducive to identify the potential mechanisms of carcinogenesis and effective therapeutic targets.

Signal transducer and activator of transcription 3 (STAT3) is one of the members of the STAT signaling protein family, which consists of seven members (STAT1, STAT2, STAT3, STAT4, STAT5a, STAT5b and STAT6) (11). STAT3, being known as a transcription factor, is involved in important physiology, including proliferative, anti-apoptotic, metastatic and angiogenic effects (12). STAT3 has been most closely associated with tumorigenesis $(13,14)$. Previous studies demonstrated that constitutive STAT3 activation was frequently detected in numerous human cancers in vitro and in vivo (15-17). Furthermore, STAT3 participated in the physiological and pathological processes of HCC, including tumor cell survival, proliferation, angiogenesis and metastasis (13). It has been previously demonstrated that the inhibition of STAT3 activation (phosphorylation of STAT3) reduces the expression of cyclooxygenase-2 (COX-2) in HCC cells (18). Additionally, it has been reported that STAT3 serves a pivotal role in malignancies associated with inflammation due to the activation of genes that promote cell proliferation, survival and invasion $(19,20)$. The activation of the STAT3 signaling pathway triggered by HBV oncoproteins is associated with the carcinogenesis and progression of HCC (21). In HCC, STAT3 is constitutively activated, which promotes human cervical cancer progression and poor prognosis $(18,19)$. Notably, STAT3 is also involved in the overexpression of COX-2 in HCC (17).

Hydrogen sulfide $\left(\mathrm{H}_{2} \mathrm{~S}\right)$ has been classified as a novel gasotransmitter together with nitric oxide (NO) and carbon monoxide (CO) (22). In the liver, $\mathrm{H}_{2} \mathrm{~S}$ can be catalyzed by both cystathionine b-synthase (CBS) and cystathionine g-lyase (CSE) (23). Accumulating studies have demonstrated that $\mathrm{H}_{2} \mathrm{~S}$ is involved in the pathophysiological progression of tumors (24-27). However, the potential mechanism of $\mathrm{H}_{2} \mathrm{~S}$ in cancer is unclear and controversial. Accumulating evidences have demonstrated that $\mathrm{H}_{2} \mathrm{~S}$ promotes cancer progression, including proliferation, migration and invasion (28-34). $\mathrm{H}_{2} \mathrm{~S}$ can protect cancer cells from chemopreventive agent $\beta$-phenylethyl isothiocyanate-induced apoptosis (30) and promote proliferation (30), which may be mediated by the increase in Akt and extracellular signal-regulated kinase (ERK) phosphorylation, and the decrease in $\mathrm{p} 21^{\mathrm{Waf} 1 / \mathrm{Cip} 1}$ expression and NO production. A recent study by our group revealed that exogenous $\mathrm{H}_{2} \mathrm{~S}$ promotes $\mathrm{C} 6$ glioma cell growth through the activation of the p38 MAPK/ERK1/2-COX-2 signaling pathway (32). Furthermore, in PLC/PRF/5 cells, exogenous $\mathrm{H}_{2} \mathrm{~S}$ exerts proliferation, anti-apoptosis, angiogenesis and migration effects via amplifying the activation of the nuclear factor $(\mathrm{NF})-\kappa \mathrm{B}$ signaling pathway (24). Those results indicate that $\mathrm{H}_{2} \mathrm{~S}$ promotes cancer cell growth. Notably, $\mathrm{H}_{2} \mathrm{~S}$ post-conditioning effectively protects isolated ischemia/reperfusion rat hearts via activation of the Janus kinase 2 (JAK2)/STAT3 signaling pathway (33). However, whether the STAT3-COX-2 signaling pathway contributes to the growth effect of exogenous $\mathrm{H}_{2} \mathrm{~S}$ on HCC cells remains unclear.

The present study was therefore designed to determine the effect of $\mathrm{H}_{2} \mathrm{~S}$ on the activation of the STAT3-COX-2 signaling pathway in $\mathrm{HCC}$ (cell line, PLC/PRF/5) cells and to investigate whether exogenous $\mathrm{H}_{2} \mathrm{~S}$ could induce proliferation and anti-apoptosis via amplification of the STAT3-COX-2 signaling pathway in PLC/PRF/5 cells.

\section{Materials and methods}

Materials. NaHS, Hoechst 33258, AG490 and NS-398 were purchased from Sigma-Aldrich (Merck KGaA, Darmstadt, Germany). Cell Counting Kit-8 (CCK-8) was supplied by Dojindo Molecular Technologies, Inc. (Kumamoto, Japan). All antibodies were supplied by Cell Signaling Technology, Inc. (Danvers, MA, USA).

Cell culture. Human hepatoma PLC/PRF/5 cells were supplied by Sun Yat-sen University Experimental Animal Center (Guangzhou, China). The PLC/PRF/5 cells were grown in RPMI 1640 medium (Sigma-Aldrich; Merck KGaA, Darmstadt, Germany) supplemented with $10 \%$ fetal bovine serum (FBS; Gibco; Thermo Fisher Scientific, Inc., Waltham, MA, USA) under an atmosphere of $5 \% \mathrm{CO}_{2}$ and at $37^{\circ} \mathrm{C}$ with 95\% air. The PLC/PRF/5 cells were collected following the indicated treatments and their total RNA and protein contents were extracted for further analyses.

Western blot analysis. Prior to western blot analysis, the following was performed: Exposure of PLC/PRF/5 cells for the indicated times $(3,6,9,12$ and $24 \mathrm{~h})$ to $500 \mu \mathrm{mol} / 1 \mathrm{NaHS}$; co-treatment of PLC/PRF/5 cells with $500 \mu \mathrm{mol} / 1 \mathrm{NaHS}$ and $30 \mu \mathrm{mol} / 1$ AG490 for $24 \mathrm{~h}$; exposure of PLC/PRF/5 cells for the indicated times $(3,6,9,12$ and $24 \mathrm{~h})$ to $500 \mu \mathrm{mol} / 1 \mathrm{NaHS}$; $\mathrm{PLC} / \mathrm{PRF} / 5$ cells were co-treated with $500 \mu \mathrm{mol} / 1 \mathrm{NaHS}$ and $20 \mu \mathrm{mol} / 1 \mathrm{NS}-398$ for $24 \mathrm{~h}$; exposure of PLC/PRF/5 cells for the indicated times $(1,3,6,9,12$ and $24 \mathrm{~h})$ to $500 \mu \mathrm{mol} / 1$ NaHS; co-treatment of PLC/PRF/5 cells with $500 \mu \mathrm{mol} / 1$ NaHS and $30 \mu \mathrm{mol} / 1$ AG490 for $24 \mathrm{~h}$; and PLC/PRF/5 cells were co-treated with $500 \mu \mathrm{mol} / 1 \mathrm{NaHS}$ and $20 \mu \mathrm{mol} / 1$ NS-398 for $24 \mathrm{~h}$. Following the aforementioned treatments, the cells were harvested and lysed with a cell lysis solution (Beyotime Institute of Biotechnology, Shanghai, China) at $4^{\circ} \mathrm{C}$ for $30 \mathrm{~min}$. Total proteins were quantified using a Pierce BCA Protein Assay kit (cat. no. P0010S; Beyotime Institute of Biotechnology). Loading buffer (Sigma-Aldrich; Merck $\mathrm{KGaA}$ ) was added to the cytosolic extracts, and upon boiling for $6 \mathrm{~min}$, equivalent volumes of supernatant from each sample were fractionated by $10 \%$ SDS-PAGE, followed by transfer of the proteins onto polyvinylidene difluoride membranes. The membranes were blocked with $5 \%$ fat-free milk for $60 \mathrm{~min}$ in fresh blocking buffer [0.1\% Tween-20 in TBS (TBST)] at room temperature, and next incubated with anti-phosphorylated (p)-STAT3 antibody (cat. no. 9145; 1:1,000 dilution), anti-STAT3 antibody (SAB1406487; 1:1,000 dilution), anti-COX-2 antibody (cat. no. 4842; 
1:1,000 dilution) or anti-cleaved caspase-3 antibody (cat. no. 9661; 1:1,000 dilution) in freshly prepared TBS-T with $3 \%$ free-fat milk overnight with gentle agitation at $4^{\circ} \mathrm{C}$. The membranes were washed for 5 min with TBS-T three times and then incubated with a horseradish peroxidase-conjugated goat anti-rabbit secondary antibody (SAB3701044; Sigma-Aldrich; Merck KGaA) at 1:2,500 dilution in TBS-T with $3 \%$ fat-free milk for $1.5 \mathrm{~h}$ at room temperature. Then, the membranes were washed three times with TBS-T for $5 \mathrm{~min}$ each. The immunoreactive signals were visualized using enhanced chemiluminescence detection. In order to quantify the protein expression, the X-ray films were scanned and analyzed with ImageJ $1.47 \mathrm{i}$ software (National Institutes of Health, Bethesda, MD, USA). The experiment was conducted three times.

Measurement of cell viability. Cells were seeded in 96-well plates at a density of $1 \times 10^{4}$ cells $/ \mathrm{ml}$ and incubated at $37^{\circ} \mathrm{C}$. Prior to the CCK-8 assay to assess cell viability, the following was performed: PLC/PRF/5 cells were treated with different concentrations $(100,200,300,400$ and $500 \mu \mathrm{mol} / \mathrm{l})$ of NaHS; treatment of PLC/PRF/5 cells with $500 \mu \mathrm{mol} / 1 \mathrm{NaHS}$ for the indicated times (12, 24, 36 and $48 \mathrm{~h})$; co-treatment of PLC/PRF/5 cells with $500 \mu \mathrm{mol} / \mathrm{l} \mathrm{NaHS}$ and different doses of AG490 (1, 10, 20 and $30 \mu \mathrm{mol} / \mathrm{l})$ for $24 \mathrm{~h}$; and PLC/PRF/5 cells were co-treated with $500 \mu \mathrm{mol} / 1 \mathrm{NaHS}$ and NS-398 (0.01-0.5 $\mu \mathrm{mol} / \mathrm{l})$ for $24 \mathrm{~h}$. Following the above treatments, $10 \mu \mathrm{l}$ CCK-8 solution at $1 / 10$ dilution was added to each well, and then the plate was incubated for $1.5 \mathrm{~h}$ at $37^{\circ} \mathrm{C}$. Absorbance at $450 \mathrm{~nm}$ was determined using a microplate reader (Molecular Devices, Sunnyvale, CA, USA). The means of the optical density (OD) values of three wells in Fig. 2A-D were used to calculate the percentage of cell viability according to the following formula: Cell viability $(\%)=(\mathrm{OD}$ treatment group/OD control group) $\mathrm{x} 100 \%$. The experiment was carried out three times.

Reverse transcription-quantitative polymerase chain reaction (RT-qPCR). RT-PCR was carried out in 200- $\mu 1$ sterile tubes (Eppendorf, Hamburg, Germany). Approximately $2 \mu \mathrm{g}$ total RNA, $1 \mu$ l oligo (dT) (Sigma-Aldrich; Merck KGaA), $1 \mu \mathrm{l}$ dNTP, and diethylpyrocarbonate were placed into the PCR System (cat. no. 204174; Qiagen, Inc., Valencia, CA, USA) for reaction at $65^{\circ} \mathrm{C}$ for $5 \mathrm{~min}$. Once the reaction had ended, the tubes were stored on ice. Then, $4 \mu 15 \mathrm{X}$ First-Strand Buffer (cat. no. 19051; Qiagen, Inc.) and $2 \mu \mathrm{l}$ DL-dithiothreitol were successively added for reaction at $37^{\circ} \mathrm{C}$ for $2 \mathrm{~min}$. Subsequently $1 \mu 1$ reverse transcriptase (M-MLV RT; cat. no. 1701; Promega Corporation, Madison, WI, USA) was added to every tube for reaction at $37^{\circ} \mathrm{C}$ for $50 \mathrm{~min}$ and then at $70^{\circ} \mathrm{C}$ for $15 \mathrm{~min}$. The primers used for RT-qPCR were as follows: STAT3 forward 5'-ACCTCCAGGACGACTTTGAT-3' and reverse 5'-TGT CTTCTGCACGTACTCCA-3'; COX-2 forward 5'-CTGTAT CCCGCCCTGCTGGTG-3' and reverse 5'-ACTTGCGTT GATGGTGGCTGTCTT-3'; and GAPDH forward 5'-GCA CCGTCAAGGCTGAGAAC-3' and reverse 5'-TGGTGA AGACGCCAGTGGA-3'. RT-qPCR was performed with the Applied Biosystems 7500 Fast Real-Time PCR System (Life technologies, Carlsbad, CA, USA). Quantitative gene amplifications were performed using the following thermocycling conditions: Initial denaturation for $5 \mathrm{~min}$ at $95^{\circ} \mathrm{C}, 40$ cycles of denaturation at $95^{\circ} \mathrm{C}$ for $5 \mathrm{sec}$ and annealing and extension at $60^{\circ} \mathrm{C}$ for $20 \mathrm{sec}$. After normalizing to the GAPDH gene, expression levels for each target gene were calculated using the comparative threshold cycle (2- $\Delta \Delta \mathrm{Cq})$ method (35).

Hoechst 33258 nuclear staining for evaluation of apoptosis. Apoptotic cell death was evaluated by Hoechst 33258 staining followed by photofluorography. First, PLC/PRF/5 cells were plated onto $35-\mathrm{mm}$ dishes at a density of $1 \times 10^{6}$ cells/well. Subsequently, the following was performed: PLC/PRF/5 cells were treated with RPMI 1640 medium for $24 \mathrm{~h}$; treatment of $\mathrm{PLC} / \mathrm{PRF} / 5$ cells with $500 \mu \mathrm{mol} / 1 \mathrm{NaHS}$ for $24 \mathrm{~h}$; co-treatment of PLC/PRF/5 cells with $500 \mu \mathrm{mol} / 1 \mathrm{NaHS}$ and $30 \mu \mathrm{mol} / 1$ AG490 for $24 \mathrm{~h}$; PLC/PRF/5 cells were co-treated with $500 \mu \mathrm{mol} / 1 \mathrm{NaHS}$ and $20 \mu \mathrm{mol} / 1 \mathrm{NS}-398$ for $24 \mathrm{~h}$; treatment of PLC/PRF/5 cells with $30 \mu \mathrm{mol} / 1 \mathrm{AG} 490$ for $24 \mathrm{~h}$; treatment of PLC/PRF/5 cells with $20 \mu \mathrm{mol} / 1 \mathrm{NS}-398$ for $24 \mathrm{~h}$; treatment of PLC/PRF/5 cells with $500 \mu \mathrm{mol} / 1 \mathrm{NaHS}$ for the indicated times (1, 3, 6, 9, 12 and 24 h); co-treatment of PLC/PRF/5 cells with $500 \mu \mathrm{mol} / 1 \mathrm{NaHS}$ and $30 \mu \mathrm{mol} / 1 \mathrm{AG} 490$ or $20 \mu \mathrm{mol} / 1$ NS-398 for $24 \mathrm{~h}$. Following the aforementioned treatments, the cells were fixed with $4 \%$ paraformaldehyde in $0.1 \mathrm{~mol} / 1$ PBS ( $\mathrm{pH}$ 7.4) for $10 \mathrm{~min}$ at $4^{\circ} \mathrm{C}$. The slides were then washed three times with PBS. Upon staining with $5 \mathrm{mg} / \mathrm{ml}$ Hoechst 33258 for $15 \mathrm{~min}$, the cells were washed three times with PBS. Finally, the cells were visualized under a fluorescence microscope (Bx50-FLA; Olympus Corporation, Tokyo, Japan). Viable PLC/PRF/5 cells displayed a uniform blue fluorescence throughout the nucleus and a normal nuclear size. By contrast, apoptotic PLC/PRF/5 cells exhibited condensed, distorted or fractured nuclei. The experiment was repeated three times.

Transwell migration assay. PLC/PRF/5 cells were seeded in 96-well plates at a density of $1 \times 10^{4}$ cells $/ \mathrm{ml}$, incubated at $37^{\circ} \mathrm{C}$ and added to the upper chamber of a Transwell membrane (Transwell Permeable Support with a 5.0- $\mu \mathrm{m}$ polycarbonate membrane, 6.5-mm insert and 24-well plate; Costar; Corning Life Sciences, Tewksbury, MA, USA). Next, $500 \mu \mathrm{l}$ of $10 \%$ FBS-RPMI-1640 (Sigma-Aldrich; Merck KGaA) was added to each bottom chamber. After $24 \mathrm{~h}$ of incubation at $37^{\circ} \mathrm{C}$, the cells that had migrated to the lower chamber were counted. Triplicate experiments were performed with each group, and the means and standard error of the mean were calculated under a fully automated inverted microscope.

ELISA for detection of VEGF in the culture supernatants. $\mathrm{PLC} / \mathrm{PRF} / 5$ cells were cultured in 96-well plates. PLC/PRF/5 cells were co-conditioned with $500 \mu \mathrm{mol} / 1 \mathrm{NaHS}$ and $30 \mu \mathrm{mol} / 1 \mathrm{AG} 490$ or $20 \mu \mathrm{mol} / 1 \mathrm{NS}-398$ for $24 \mathrm{~h}$. Following these treatments, the level of VEGF in the culture media was evaluated using a Human VEGF ELISA kit (cat. no. RAB0507; Sigma-Aldrich; Merck KGaA) according to the manufacturer's protocol. The experiment was performed $\geq 5$ times.

Statistical analysis. All data are presented as the mean \pm standard error of the mean. Differences between groups were analyzed by one-way analysis of variance using SPSS 13.0 software (SPSS, Inc., Chicago, IL, USA), followed by a least significant difference post hoc comparison test. $\mathrm{P}<0.05$ was considered to indicate a statistically significant difference. 
A

C

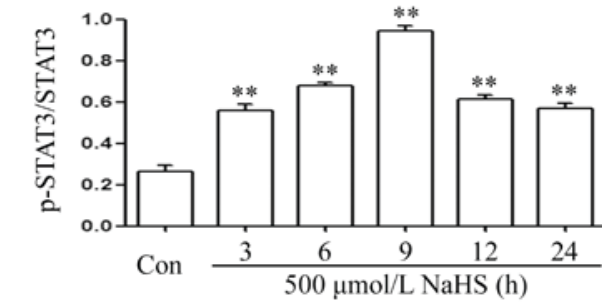

E
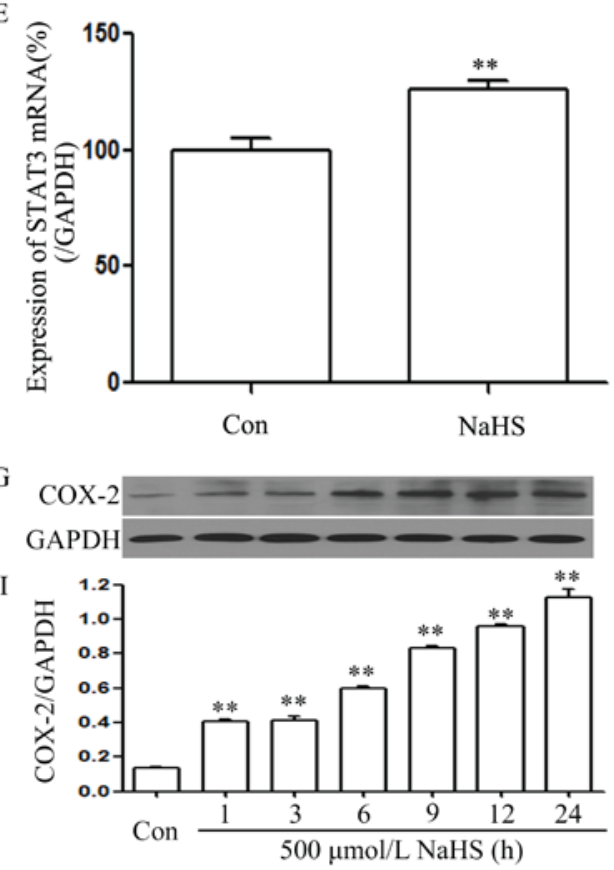

B

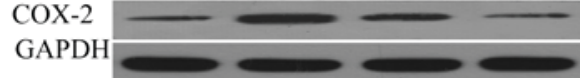

$\mathrm{D}$

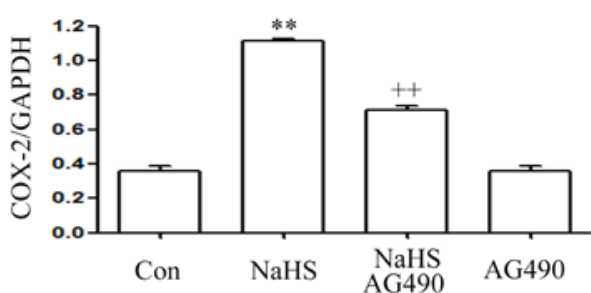

F

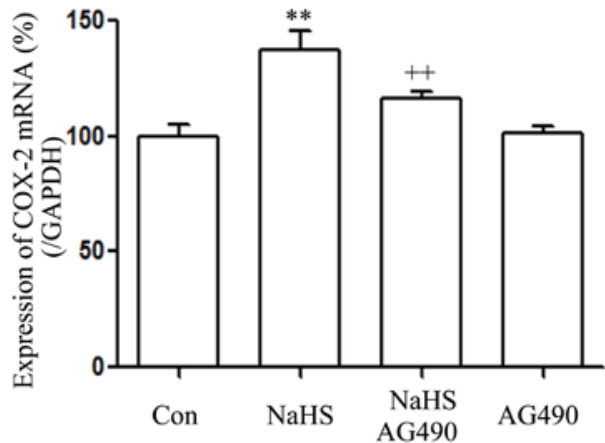

H

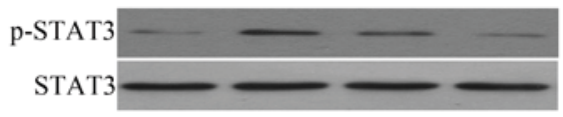

J

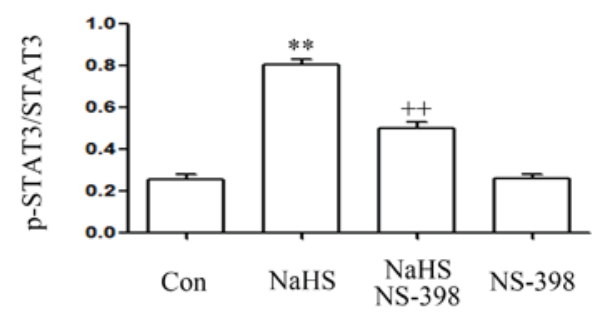

Figure 1. NaHS activates the STAT3-COX-2 signaling pathway in PLC/PRF/5 cells. (A) Exposure of PLC/PRF/5 cells for the indicated times (3, 6, 9, 12 and $24 \mathrm{~h})$ to $500 \mu \mathrm{mol} / 1 \mathrm{NaHS}$; (B) co-treatment of PLC/PRF/5 cells with $500 \mu \mathrm{mol} / 1 \mathrm{NaHS}$ and $30 \mu \mathrm{mol} / 1 \mathrm{AG} 490$ for $24 \mathrm{~h}$; (C) the rate of p-STAT3/STAT3; (D) the rate of COX-2/GAPDH; (E) the expression of STAT3 mRNA; (F) the expression of COX-2 mRNA; (G) exposure of PLC/PRF/5 cells for the indicated times (3, 6, 9, 12 and $24 \mathrm{~h}$ ) to $500 \mu \mathrm{mol} / 1 \mathrm{NaHS}$; (H) PLC/PRF/5 cells were co-treated with $500 \mu \mathrm{mol} / 1 \mathrm{NaHS}$ and $20 \mu \mathrm{mol} / 1$ NS-398 for $24 \mathrm{~h}$; (I) the rate of COX-2/GAPDH; (J) the rate of p-STAT3/STAT3. The expression levels of p-STAT3 (A, C, H and J) and COX-2 (B, D, G and I) were semiquantified by western blot assay. (C, D, I and J) Densitometric analysis of the p-STAT3 expression levels shown in panels A, B, G and H, respectively. The mRNA expression levels of (E) STAT3 and (F) COX-2 in PLC/PRF/5 cells were examined by semiquantitative reverse transcription-polymerase chain reaction. GAPDH mRNA was used as a loading control. Data are presented as means \pm standard error of the mean $(n=3) .{ }^{* *} \mathrm{P}<0.01$ vs. the control group. ${ }^{++} \mathrm{P}<0.01$ vs. the group treated with $\mathrm{NaHS}$, a donor of $\mathrm{H}_{2} \mathrm{~S}$. Con, control; STAT3, signal transducer and activator of transcription 3; COX-2, cyclooxygenase-2; p-, phosphorylated.

\section{Results}

NaHS activates the STAT3-COX-2 signaling pathway in PLC/PRF/5 cells. As shown in Fig. 1A and C, exposure of $\mathrm{PLC} / \mathrm{PRF} / 5$ cells for the indicated times $(3,6,9,12$ and $24 \mathrm{~h})$ to $500 \mu \mathrm{mol} / 1 \mathrm{NaHS}$ markedly enhanced the expression level of p-STAT3, reaching a maximal peak at $9 \mathrm{~h}$, while the expression level of STAT3 was not altered. Furthermore, exposure of the cells to $500 \mu \mathrm{mol} / 1 \mathrm{NaHS}$ for $24 \mathrm{~h}$ markedly increased STAT3 mRNA expression (Fig. 1E). This indicates that the STAT3 signaling pathway is activated in NaHS-induced $\mathrm{PLC} / \mathrm{PRF} / 5$ cell growth.

As shown in Fig. $1 \mathrm{G}$ and $\mathrm{I}$, exposure of PLC/PRF/5 cells for the indicated times $(3,6,9,12$ and $24 \mathrm{~h})$ to $500 \mu \mathrm{mol} / \mathrm{l} \mathrm{NaHS}$ markedly enhanced the expression level of COX-2, reaching a maximal peak at $24 \mathrm{~h}$. Exposure of the cells to $500 \mu \mathrm{mol} / 1$ NaHS for $24 \mathrm{~h}$ markedly increased COX-2 mRNA expression
(Fig. 1F). This indicates that the COX-2 signaling pathway was also activated in the NaHS-induced PLC/PRF/5 cell growth.

Notably, co-treatment of PLC/PRF/5 cells with $500 \mu \mathrm{mol} / \mathrm{l}$ $\mathrm{NaHS}$ and $30 \mu \mathrm{mol} / \mathrm{l} \mathrm{AG} 490$ for $24 \mathrm{~h}$ considerably suppressed the NaHS-induced increase in the expression levels of COX-2 (Fig. 1B and D) and COX-2 mRNA (Fig. 1F). Alone, treatment of cells with $30 \mu \mathrm{mol} / 1 \mathrm{AG} 490$ for $24 \mathrm{~h}$ did not alter the basal expression level of COX-2 mRNA. This indicates that COX-2 was located downstream of STAT3 in the signaling pathway. Notably, co-treatment of PLC/PRF/5 cells with $500 \mu \mathrm{mol} / 1$ NaHS and $20 \mu \mathrm{mol} / \mathrm{l} \mathrm{NS}-398$ for $24 \mathrm{~h}$ suppressed the expression of p-STAT3 (Fig. 1H and J). Therefore, it can be deduced that there was interaction between the STAT3 and COX-2 signaling pathways.

The STAT3-COX-2 signaling pathway participates in the NaHS-induced increase in cell viability in PLC/PRF/5 cells. 

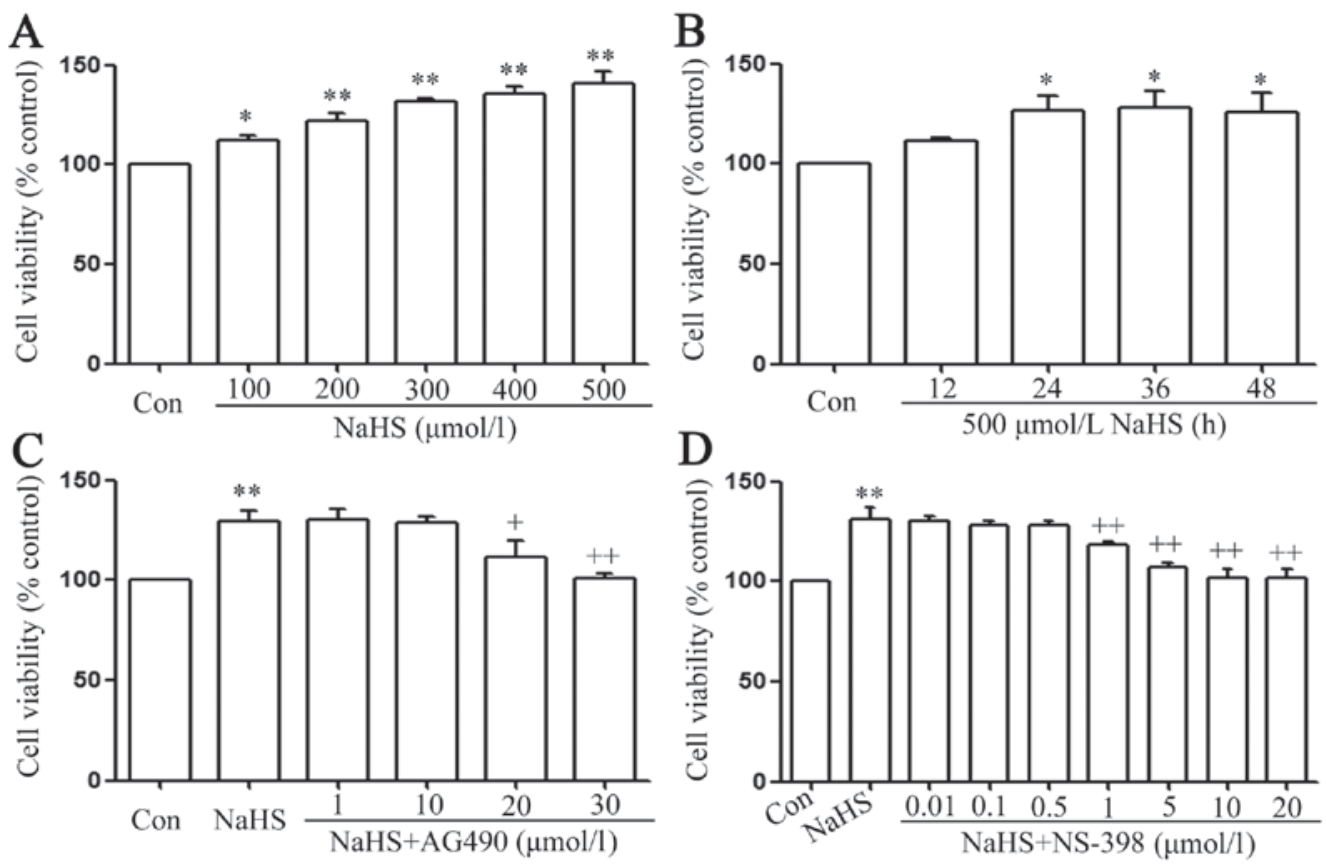

Figure 2. The signal transducer and activator of transcription 3-cyclooxygenase-2 signaling pathway serves a function in NaHS-induced increase in cell viability in PLC/PRF/5 cells. (A) PLC/PRF/5 cells were treated with different concentration (100, 200, 300, 400 and 500 $\mu$ mol/1) of NaHS. (B) Treatment of PLC/PRF/5 cells with $500 \mu \mathrm{mol} / 1 \mathrm{NaHS}$ for the indicated times (12, 24,36 and $48 \mathrm{~h})$. (C) co-treatment of PLC/PRF/5 cells with 500 $\mu \mathrm{mol} / 1 \mathrm{NaHS}$ and different doses of AG490 (1, 10, 20 and $30 \mu \mathrm{mol} / 1)$ for 24 h. (D) PLC/PRF/5 cells were co-treated with $500 \mu \mathrm{mol} / 1$ NaHS and NS-398 (0.01-0.5 $\mu \mathrm{mol} / 1)$ for 24 h. Cell viability was detected by Cell Counting Kit- 8 assay. Data are presented as the mean \pm standard error of the mean ( $\mathrm{n}=5$ ). ${ }^{*} \mathrm{P}<0.05$, *** $\mathrm{P}<0.01$ vs. the control group. ${ }^{+} \mathrm{P}<0.05,{ }^{++} \mathrm{P}<0.01$ vs. with the NaHS-treated group. Con, control.

As shown in Fig. 2A, doses of NaHS from 100 to $500 \mu \mathrm{mol} / 1$ markedly promoted cell proliferation, leading to an increase in cell viability and reaching a maximal peaking at $500 \mu \mathrm{mol} / \mathrm{l}$. Treatment of PLC/PRF/5 cells with $500 \mu \mathrm{mol} / 1 \mathrm{NaHS}$ for the indicated times $(12,24,36$ and $48 \mathrm{~h})$ markedly promoted cell proliferation, reaching the maximal proliferative effect at $24 \mathrm{~h}$. Based on the above results, PLC/PRF/5 cells were treated with $500 \mu \mathrm{mol} / 1 \mathrm{NaHS}$ for $24 \mathrm{~h}$ in all subsequent experiments. As shown in Fig. 2C, the increased cell viability was suppressed by co-treatment with $500 \mu \mathrm{mol} / 1 \mathrm{NaHS}$ and different doses of AG490 (a specific inhibitor of the STAT3 signaling pathway) (36) for $24 \mathrm{~h}$. Doses of AG490 from 1 to $10 \mu \mathrm{mol} / 1$ did not change cell viability. On the contrary, doses of AG490 from 20 to $30 \mu \mathrm{mol} / 1$ significantly suppressed cell proliferation, leading to a decrease in cell viability. According to the above results, PLC/PRF/5 cells were co-treated with $500 \mu \mathrm{mol} / 1 \mathrm{NaHS}$ and $30 \mu \mathrm{mol} / \mathrm{l} \mathrm{AG490}$ for $24 \mathrm{~h}$ in all subsequent experiments. Doses of NS-398 from 0.01 to $0.5 \mu \mathrm{mol} / 1$ did not change cell viability, while doses of NS-398 from 1 to $20 \mu \mathrm{mol} / 1$ significantly suppressed cell proliferation, leading to a decrease in cell viability, which reached a minimum at 10 and $20 \mu \mathrm{mol} / 1$. According to the above results, PLC/PRF/5 cells were co-treated with $500 \mu \mathrm{mol} / 1 \mathrm{NaHS}$ and $20 \mu \mathrm{mol} / 1$ NS-398 for $24 \mathrm{~h}$ in all subsequent experiments.

The STAT3-COX-2 signaling pathway participates in NaHS-induced anti-apoptosis in PLC/PRF/5 cells. It was demonstrated that exposure of cells to $500 \mu \mathrm{mol} / 1 \mathrm{NaHS}$ for $24 \mathrm{~h}$ markedly enhanced cell proliferation, as evidenced by a decrease in the number of apoptotic cells (Fig. 3Ab and Ag). In addition, the above anti-apoptosis was nearly completely inhibited by co-treating PLC/PRF/5 cells with $500 \mu \mathrm{mol} / 1$ NaHS and $30 \mu \mathrm{mol} / 1 \mathrm{AG} 490$ or $20 \mu \mathrm{mol} / 1 \mathrm{NS}-398$ for $24 \mathrm{~h}$. Furthermore, exposure of cells to $500 \mu \mathrm{mol} / 1 \mathrm{NaHS}$ for $24 \mathrm{~h}$ markedly decreased cleaved caspase-3 expression (Fig. 3Ba and Bc), and the NaHS-induced decrease in the expression level of cleaved caspase- 3 was inhibited by co-treating $\mathrm{PLC} / \mathrm{PRF} / 5$ cells with $500 \mu \mathrm{mol} / 1 \mathrm{NaHS}$ and $30 \mu \mathrm{mol} / 1 \mathrm{AG} 490$ or $20 \mu \mathrm{mol} / 1 \mathrm{NS}-398$ for $24 \mathrm{~h}$ (Fig. 3Bb and d).

The STAT3-COX-2 signaling pathway participates in NaHS-induced migration in PLC/PRF/5 cells. As shown in Fig. 4, NaHS significantly enhanced the expression levels of matrix metalloproteinase-2 (MMP-2) (Fig. 4A and C) and promoted migration (Fig. 4G) in PLC/PRF/5 cells. These NaHS-induced effects were inhibited by co-treating $\mathrm{PLC} / \mathrm{PRF} / 5$ cells with $500 \mu \mathrm{mol} / 1 \mathrm{NaHS}$ and $30 \mu \mathrm{mol} / 1 \mathrm{AG} 490$ or $20 \mu \mathrm{mol} / 1 \mathrm{NS}-398$ for $24 \mathrm{~h}$ (Fig. 3Bb and d).

The STAT3-COX-2 signaling pathway participates in the NaHS-induced production of VEGF in PLC/PRF/5 cells. As shown in Fig. 5, the level of VEGF was markedly increased in NaHS-treated PLC/PRF/5 cells, compared with that in the control group $(\mathrm{P}<0.01)$. However, this increase in the level of VEGF was significantly suppressed by co-treatment of cells with $500 \mu \mathrm{mol} / 1 \mathrm{NaHS}$ and $30 \mu \mathrm{mol} / 1 \mathrm{AG} 490$ or $20 \mu \mathrm{mol} / 1$ NS-398 for $24 \mathrm{~h}$.

\section{Discussion}

Previous studies have demonstrated that STAT3 $(13,16)$ and COX-2 (24) are associated with the progression of tumors. 
A Hoechst staining
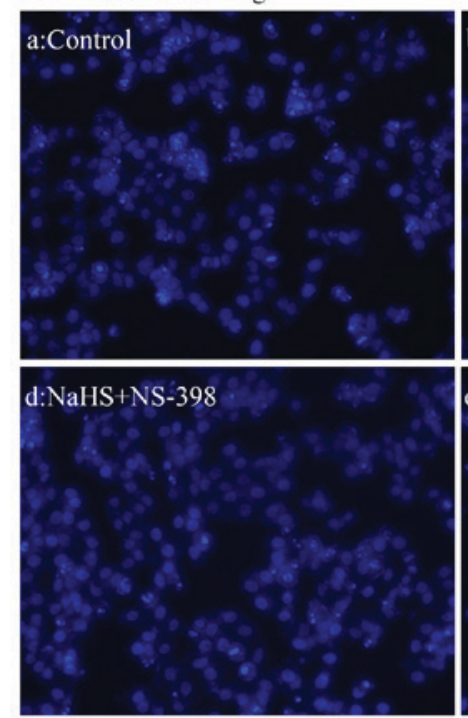

g
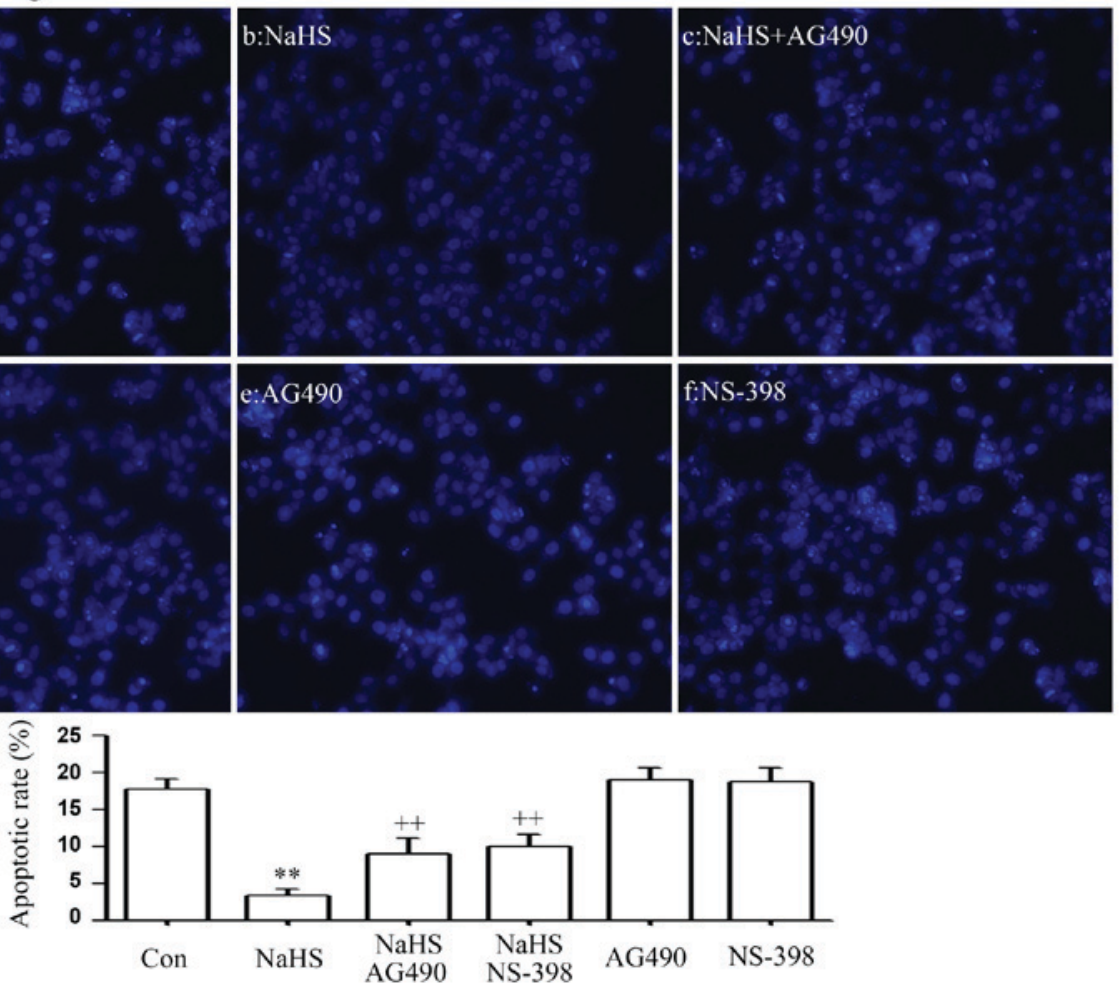

B Western blot
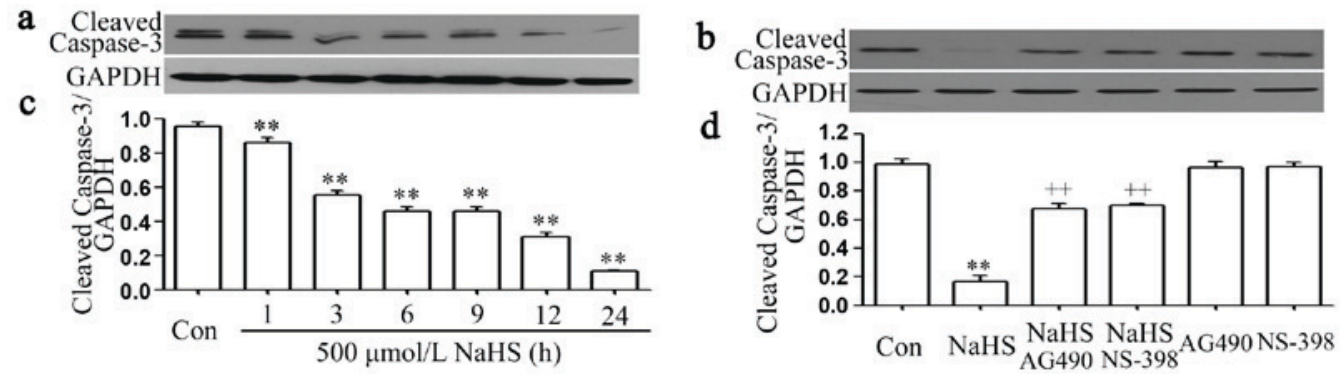

Figure 3. The signal transducer and activator of transcription 3-cyclooxygenase-2 signaling pathway serves a function in NaHS-induced anti-apoptosis in PLC/PRF/5 cells. (A) Following the indicated treatments: (Aa) PLC/PRF/5 cells were treated with RPMI 1640 medium for 24 h; (Ab) Treatment of PLC/PRF/5 cells with $500 \mu \mathrm{mol} / 1 \mathrm{NaHS}$ for $24 \mathrm{~h}$; (Ac) co-treatment of PLC/PRF/5 cells with $500 \mu \mathrm{mol} / 1 \mathrm{NaHS}$ and $30 \mu \mathrm{mol} / 1 \mathrm{AG} 490$ for $24 \mathrm{~h}$; (Ad) PLC/PRF/5 cells were co-treated with $500 \mu \mathrm{mol} / 1 \mathrm{NaHS}$ and $20 \mu \mathrm{mol} / 1 \mathrm{NS}-398$ for 24h; (Ae) Treatment of PLC/PRF/5 cells with $30 \mu \mathrm{mol} / 1 \mathrm{AG} 490$ for $24 \mathrm{~h}$; (Af) treatment of PLC/PRF/5 cells with $20 \mu \mathrm{mol} / 1 \mathrm{NS}-398$ for $24 \mathrm{~h}$; (Ba and Bc) Treatment of PLC/PRF/5 cells with $500 \mu \mathrm{mol} / 1 \mathrm{NaHS}$ for the indicated times (1, 3, 6, 9,12 and $24 \mathrm{~h}$ ); (B-b and d) co-treatment of PLC/PRF/5 cells with $500 \mu \mathrm{mol} / 1 \mathrm{NaHS}$ and $30 \mu \mathrm{mol} / 1 \mathrm{AG} 490$ or $20 \mu \mathrm{mol} / 1 \mathrm{NS}-398 \mathrm{for} 24 \mathrm{~h}$. Cellular apoptosis was assessed by Hoechst 33258 staining, followed by photofluorography at x100 magnification. (B) Western blotting demonstrated varying expression of cleaved caspase-3 associated with $(\mathrm{Ba})$ the times treated with NaHS and $(\mathrm{Bb})$ the different treatment groups. (Bc) Densitometric analysis identified that differences due to time of treatment were significant. (Bd) A number of the differences in cleaved caspase-3 expression as a result of different treatment groups were significant. Data are presented as the mean \pm standard error of the mean $(n=3) .{ }^{* *} \mathrm{P}<0.01$ vs. the control group. ${ }^{++} \mathrm{P}<0.01$ vs. the NaHS-treated group. Con, control.

Inhibition of the STAT3 (34) or COX-2 (37) signaling pathways can contribute to the inhibitory effect of tumor growth. The present study extends these previous findings and provides new evidence that the STAT3-COX-2 signaling pathway is associated with the growth of PLC/PRF/5 cells, as evidenced by the increased expression levels of STAT3 and COX-2. Importantly, the present study has demonstrated for the first time that exogenous $\mathrm{H}_{2} \mathrm{~S}$ promotes $\mathrm{PLC} / \mathrm{PRF} / 5$ cell proliferation and anti-apoptosis by activating the STAT3-COX-2 signaling pathway.

$\mathrm{H}_{2} \mathrm{~S}$ has been classified as a novel gasotransmitter together with NO and CO (22). Its broad range of physiological functions, including cardioprotective (38), angiogeneic (39), antioxidant (40), and pro- and anti-inflammatory activities (38), are attracting widespread attention at present. In the liver, $\mathrm{H}_{2} \mathrm{~S}$ can exert hepatoprotective effects via miR-34a-mediated modulation of the nuclear factor erythroid 2-related factor 2 signaling pathway (41). Recently, our group demonstrated that exogenous $\mathrm{H}_{2} \mathrm{~S}$ promoted PLC/PRF/5 cell proliferation, anti-apoptosis, angiogenesis and migration by amplifying the activation of the $\mathrm{NF}-\kappa \mathrm{B}$ signaling pathway (24). To further investigate the effect of exogenous $\mathrm{H}_{2} \mathrm{~S}$ on PLC/PRF/5 cells, PLC/PRF/5 cells were treated with $500 \mu \mathrm{mol} / 1 \mathrm{NaHS}$ for $24 \mathrm{~h}$. The results revealed that exogenous $\mathrm{H}_{2} \mathrm{~S}$ increased PLC/PRF/5 cell growth, angiogenesis and migration, as evidenced by an increase in cell viability, 
A
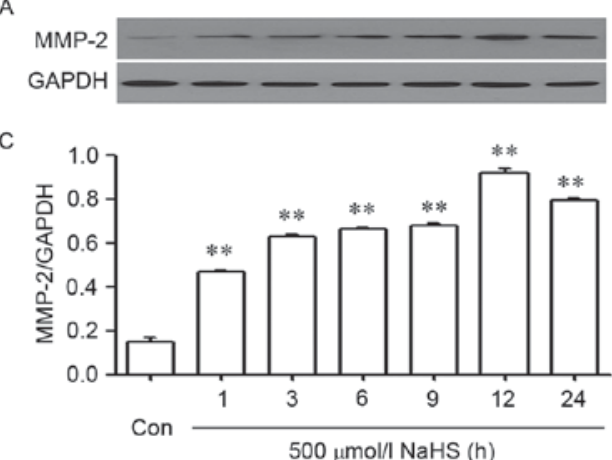

E

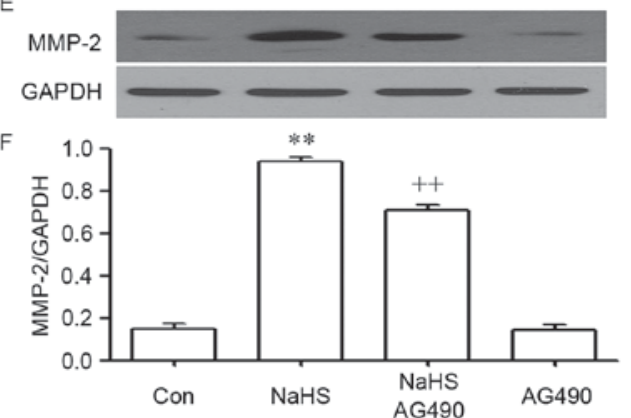

B

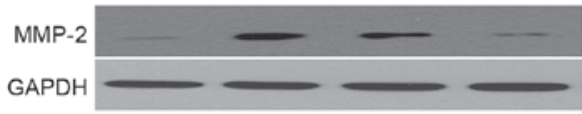

D
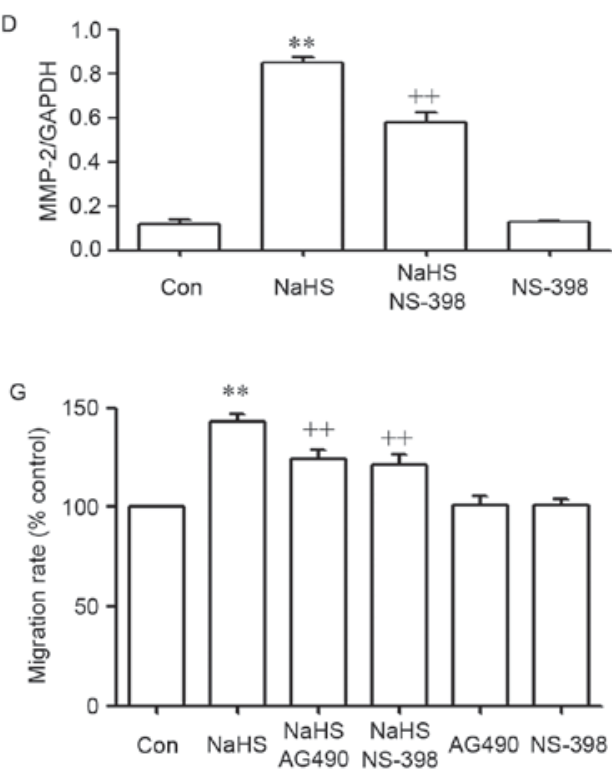

Figure 4. The STAT3-COX2 signaling pathway participates in NaHS-induced migration in PLC/PRF/5 cells. (A) Exposure of PLC/PRF/5 cells for the indicated times $(1,3,6,9,12$ and $24 \mathrm{~h})$ to $500 \mu \mathrm{mol} / 1 \mathrm{NaHS}$; (B) the rate of MMP-2/GAPDH; (C) co-treatment of PLC/PRF/5 cells with 500 $\mu \mathrm{mol} / 1 \mathrm{NaHS}$ and $30 \mu \mathrm{mol} / 1 \mathrm{AG} 490$ for $24 \mathrm{~h}$; (D) the rate of MMP-2/GAPDH; (E) PLC/PRF/5 cells were co-treated with 500 $\mu \mathrm{mol} / 1 \mathrm{NaHS}$ and $20 \mu \mathrm{mol} / 1 \mathrm{NS}-398 \mathrm{for} 24 \mathrm{~h}$; (F) the rate of MMP-2/GAPDH; (G) PLC/PRF/5 cells were co-treated with $500 \mu \mathrm{mol} / 1 \mathrm{NaHS}$ and $30 \mu \mathrm{mol} / 1 \mathrm{AG} 490$, or $20 \mu \mathrm{mol} / 1 \mathrm{NS}-398 \mathrm{for} 24 \mathrm{~h}$. (A-F) The expression levels of MMP-2 were semiquantified by western blot assay. (C, D and F) Densitometric analysis of the p-STAT3 expression levels shown in panels A-C, respectively. (G) Cell migration was evaluated by Transwell migration assay, and the migration rate was calculated under a fully automated inverted microscope. Data are presented as the mean \pm standard error of the mean $(n=3) .{ }^{* *} \mathrm{P}<0.01$ vs. the control group. ${ }^{++} \mathrm{P}<0.01$ vs. the NaHS-treated group. MMP-2, matrix metalloproteinase-2; Con, control.

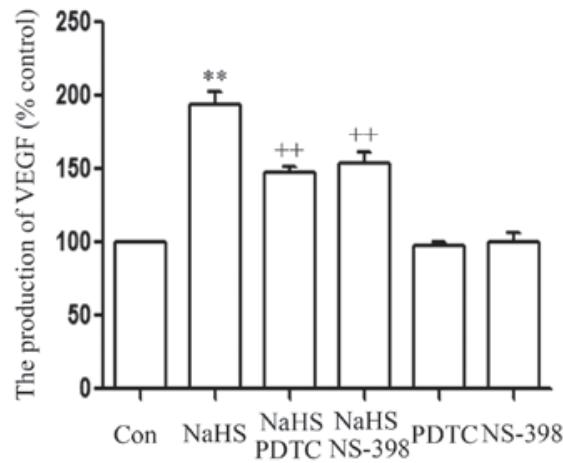

Figure 5. The signal transducer and activator of transcription 3-cyclooxygenase-2 signaling pathway serves a function in the NaHS-induced production of VEGF in PLC/PRF/5 cells. PLC/PRF/5 cells were co-conditioned with $500 \mu \mathrm{mol} / 1 \mathrm{NaHS}$ and $30 \mu \mathrm{mol} / 1 \mathrm{AG} 490$ or $20 \mu \mathrm{mol} / 1 \mathrm{NS}-398$ for $24 \mathrm{~h}$. ELISA was used to measure the production of VEGF. Data are presented as the mean \pm standard error $(n=3) .{ }^{* *} \mathrm{P}<0.01$ vs. the control group; ${ }^{++} \mathrm{P}<0.01$ vs. the NaHS-treated group. VEGF, vascular endothelial growth factor; Con, control; PDTC, pyrrolidine dithiocarbamate.

migration, expression of MMP-2 and production of VEGF, and a decrease in apoptotic rate and expression of caspase- 3 (one of the apoptotic factors) (42), which is consistent with the findings of our previous study (23).

Furthermore, it was observed that the expression levels of p-STAT3, STAT3 mRNA, COX-2 protein and COX-2 mRNA were upregulated in NaHS-treated PLC/PRF/5 cells. This indicates that exogenous $\mathrm{H}_{2} \mathrm{~S}$ can activate the STAT3 and COX-2 signaling pathways in PLC/PRF/5 cells. Previous studies have shown that the STAT3 (13-17) and COX-2 (32,43-45) signaling pathways are associated with tumorigenesis. The present study hypothesized that the STAT3 and COX-2 signaling pathways may be involved in the effects of exogenous $\mathrm{H}_{2} \mathrm{~S}$ on the growth of PLC/PRF/5 cells. In order to corroborate our hypothesis, PLC/PRF/5 cells were co-treated with NaHS and AG490 (an inhibitor of STAT3) (36) or NS-398. Our data revealed that co-treatment of PLC/PRF/5 cells with NaHS and AG490 or NS-398 markedly alleviated the NaHS-induced cell growth effects, including proliferation, angiogenesis, migration and anti-apoptosis. These results suggest that NaHS-induced PLC/PRF/5 cell growth is at least in part associated with the activated STAT3 and COX-2 signaling pathways.

A novel finding of the present study is the interaction between STAT3 and COX-2 in PLC/PRF/5 cells. COX-2 is ever-present as a downstream effector of the STAT3 signaling pathway in various cancer cells (46-48). A previous study has demonstrated that the inhibition of STAT3 activation reduces the expression of COX-2 in SMMC-7721 cells (18). This indicates that COX-2 is a downstream effector of the STAT3 signaling pathway in liver cancer. Additionally, COX-2 is located upstream of the STAT3 signaling pathway in various cancer cells. Liu et al (49) observed that COX-2/prostaglandin E2 regulated JAK2/STAT3 signaling in colorectal cancer cells (49). Furthermore, Xiong et al (50) revealed that there is a positive feedback loop between the STAT3 and COX-2 genes that may contribute to Helicobacter pylori-associated human gastric tumorigenesis (50). However, the exact association 
between STAT3 and COX-2 in cell proliferation, migration and apoptosis in PLC/PRF/5 cells is not completely understood. The present study provided novel evidence that there is a positive interaction between the STAT3 and COX-2 signaling pathways, which may be an important mechanism responsible for cell proliferation and anti-apoptosis in PLC/PRF/5 cells. This mechanism is supported by the following results: i) Treatment of PLC/PRF/5 cells with NaHS and AG490 attenuated the expression level of COX-2; ii) treatment of PLC/PRF/5 cells with NaHS and NS-398 attenuated the expression level of p-STAT3; and iii) exposure of PLC/PRF/5 cells to AG490 or NS-398 induced growth inhibition and apoptosis, as demonstrated by the decrease in cell viability, and the increase in the number of apoptotic cells and cleaved caspased-3 expression.

To conclude, the present study provides novel evidence that the activation of the STAT3-COX-2 signaling pathway contributes to HCC carcinogenesis, including cell proliferation and anti-apoptosis. Understanding the roles of such a signaling pathway is important, as it may lead to the development of novel treatment strategies designed to inhibit this signaling cascade in $\mathrm{PLC} / \mathrm{PRF} / 5$ cells. In addition, the interaction between STAT3 and COX-2 in PLC/PRF/5 cells may serve a crucial role in PLC/PRF/5 carcinogenesis, however understanding of any additional roles remain unclear and must be investigated. Additionally, the present study provides important new insight into the molecular mechanisms underlying the promotion of cell proliferation and apoptosis by $\mathrm{H}_{2} \mathrm{~S}$ in $\mathrm{PLC} / \mathrm{PRF} / 5$ cells. First, $\mathrm{H}_{2} \mathrm{~S}$ increases cell viability and reduces apoptosis. Second, NaHS-induced growth inhibition and apoptosis appear to be linked to the inhibition of the activation of the STAT3-COX-2 signaling pathway. In HCC, these findings provide a novel insight into CBS- and CSE-derived $\mathrm{H}_{2} \mathrm{~S}$ as an endogenous tumor-promoting factor and anticancer drug target.

\section{References}

1. Forner A, Llovet JM and Bruix J: Hepatocellular carcinoma. Lancet 379: 1245-1255, 2012.

2. Bruix J, Boix L, Sala M and Llovet JM: Focus on hepatocellular carcinoma. Cancer Cell 5: 215-219, 2004.

3. Lupberger J and Hildt E: Hepatitis B virus-induced oncogenesis. World J Gastroenterol 13: 74-81, 2007.

4. Verslype C, Van Cutsem E, Dicato M, Arber N, Berlin JD, Cunningham D, De Gramont A, Diaz-Rubio E, Ducreux M, Gruenberger T, et al: The management of hepatocellular carcinoma. current expert opinion and recommendations derived from the 10th World Congress on Gastrointestinal Cancer, Barcelona, 2008. Ann Oncol 20 (Suppl 7): Svii1-Svii6, 2009.

5. Wang $\mathrm{H}$ and Chen L: Tumor microenviroment and hepatocellular carcinoma metastasis. J Gastroenterol Hepatol 28 (Suppl 1) S43-S48, 2013.

6. Iakova P, Timchenko L and Timchenko NA: Intracellular signaling and hepatocellular carcinoma. Semin Cancer Biol 21 : 28-34, 2011.

7. Faivre S, Bouattour M and Raymond E: Novel molecular therapies in hepatocellular carcinoma. Liver Int 31 (Suppl 1): S151-S160, 2011.

8. Chuang SC, La Vecchia C and Boffetta P: Liver cancer: Descriptive epidemiology and risk factors other than HBV and HCV infection. Cancer Lett 286: 9-14, 2009.

9. Liang X, Bi S, Yang W, Wang L, Cui G, Cui F, Zhang Y, Liu J, Gong X, Chen Y, et al: Epidemiological serosurvey of hepatitis B in China-declining HBV prevalence due to hepatitis B vaccination. Vaccine 27: 6550-6557, 2009.

10. Zheng B, Zhu YJ, Wang HY and Chen L: Gender disparity in hepatocellular carcinoma (HCC): Multiple underlying mechanisms. Sci China Life Sc 60: 575-584, 2017.
11. Levy DE and Darnell JE Jr: Stats: Transcriptional control and biological impact. Nat Rev Mol Cell Biol 3: 651-662, 2002.

12. Yu H, Pardoll D and Jove R: STATs in cancer inflammation and immunity: A leading role for STAT3. Nat Rev Cancer 9: 798-809, 2009.

13. Aggarwal BB, Kunnumakkara AB, Harikumar KB, Gupta SR Tharakan ST, Koca C, Dey S and Sung B: Signal transducer and activator of transcription-3, inflammation and cancer: How intimate is the relationship? Ann N Y Acad Sci 1171: 59-76, 2009.

14. Aggarwal BB, Sethi G, Ahn KS, Sandur SK, Pandey MK, Kunnumakkara AB, Sung B and Ichikawa H: Targeting signal-transducer-and-activator-of-transcription-3 for prevention and therapy of cancer: modern target but ancient solution. Ann N Y Acad Sci 1091: 151-169, 2006.

15. Zhao T, Ren H, Wang X, Liu P, Yan F, Jiang W, Li Y, Li J, Gribben JG, Jia L and Hao J: Rituximab-induced HMGB1 release is associated with inhibition of STAT3 activity in human diffuse large B-cell lymphoma. Oncotarget 6: 27816-27831, 2015.

16. Mukthavaram R, Ouyang X, Saklecha R, Jiang P, Nomura N, Pingle SC, Guo F and Makale M: Effect of the JAK2/STAT3 inhibitor SAR317461 on human glioblastoma tumorspheres. J Transl Med 13: 269, 2015.

17. Liao XH, Zheng L, He HP, Zheng DL, Wei ZQ, Wang N, Dong J, Ma WJ and Zhang TC: STAT3 regulated ATR via microRNA-383 to control DNA damage to affect apoptosis in A431 cells. Cell Signal 27: 2285-2295, 2015.

18. He S, Lu G, Hou H, Zhao Z, Zhu Z, Lu X, Chen J and Wang Z: Saikosaponin-d suppresses the expression of cyclooxygenase-2 through the phospho-signal transducer and activator of transcription 3/hypoxia-inducible factor-1 $\alpha$ pathway in hepatocellular carcinoma cells. Mol Med Rep 10: 2556-2562, 2014.

19. Loncle C, Bonjoch L, Folch-Puy E, Lopez-Millan MB, Lac S, Molejon MI, Chuluyan E, Cordelier P, Dubus P, Lomberk G, et al: IL-17 functions through the novel REG3 $\beta$-JAK2-STAT3 inflammatory pathway to promote the transition from chronic pancreatitis to pancreatic cancer. Cancer Res 75: 4852-4862, 2015.

20. Rokavec M, Öner MG and Hermeking H: lnflammation-induced epigenetic switches in cancer. Cell Mol Life Sci 73: 23-39, 2015.

21. Choudhari SR, Khan MA, Harris G, Picker D, Jacob GS, Block T and Shailubhai K: Deactivation of Akt and STAT3 signaling promotes apoptosis, inhibits proliferation and enhances the sensitivity of hepatocellular carcinoma cells to an anticancer agent, Atiprimod. Mol Cancer Ther 6: 112-121, 2007.

22. Kilburn KH, Thrasher JD and Gray MR: Low-level hydrogen sulfide and central nervous system dysfunction. Toxicol Ind Health 26: 387-405, 2010.

23. Kamoun P: Endogenous production of hydrogen sulfide in mammals. Amino Acids 26: 243-254, 2004.

24. Zhen Y, Pan W, Hu F, Wu H, Feng J, Zhang Y and Chen J: Exogenous hydrogen sulfide exerts proliferation/anti-apoptosis/angiogenesis/migration effects via amplifying the activation of NF- $\mathrm{B}$ pathway in PLC/PRF/5 hepatoma cells. Int J Oncol 46: 2194-2204, 2015.

25. Wu D, Si W, Wang M, Lv S, Ji A and Li Y: Hydrogen sulfide in cancer: Friend or foe? Nitric Oxide 50: 38-45, 2015.

26. Lee ZW and Deng LW: Role of H2S donors in cancer biology. Handb Exp Pharmacol 230: 243-265, 2015.

27. Hellmich MR and Szabo C: Hydrogen sulfide and cancer. Handb Exp Pharmacol 230: 233-241, 2015.

28. Szabo C, Coletta C, Chao C, Módis K, Szczesny B, Papapetropoulos A and Hellmich MR: Tumor-derived hydrogen sulfide, produced by cystathionine- $\beta$-synthase, stimulates bioenergetics, cell proliferation and angiogenesis in colon cancer. Proc Natl Acad Sci USA 110: 12474-12479, 2013.

29. DU SX, Xiao J, Guan F, Sun LM, Wu WS, Tang H, DU JB, Tang CS and Jin HF: Predictive role of cerebrospinal fluid hydrogen sulfide in central nervous system leukemia. Chin Med J (Engl) 124: 3450-3454, 2011.

30. Rose P, Moore PK, Ming SH, Nam OC, Armstrong JS and Whiteman M: Hydrogen sulfide protects colon cancer cells from chemopreventative agent betaphenylethyl isothiocyanate induced apoptosis. World J Gastroenterol 11: 3990-3997, 2005.

31. Cai WJ, Wang MJ, Ju LH, Wang C and Zhu YC: Hydrogen sulfide induces human colon cancer cell proliferation: Role of Akt, ERK and p21. Cell Biol Int 34: 565-572, 2010.

32. Zhen Y, Zhang W, Liu C, He J, Lu Y, Guo R, Feng J, Zhang Y and Chen J: Exogenous hydrogen sulfide promotes C6 glioma cell growth through activation of the p38 MAPK/ERK1/2-COX-2 pathways. Oncol Rep 34: 2413-2422, 2015. 
33. Luan HF, Zhao ZB, Zhao QH, Zhu P, Xiu MY and Ji Y: Hydrogen sulfide postconditioning protects isolated rat hearts against ischemia and reperfusion injury mediated by the JAK2/STAT3 survival pathway. Braz J Med Biol Res 45: 898-905, 2012.

34. Hu A, Huang JJ, Jin XJ, Li JP, Tang YJ, Huang XF, Cui HJ, $\mathrm{Xu} \mathrm{WH}$ and Sun GB: Curcumin suppresses invasiveness and vasculogenic mimicry of squamous cell carcinoma of the larynx through the inhibition of JAK-2/STAT-3 signaling pathway. Am J Cancer Res 5: 278-288, 2014.

35. Livak KJ and Schmittgen TD: Analysis of relative gene expression data using real-time quantitative PCR and the 2(-Delta Delta $\mathrm{C}(\mathrm{T})$ ) method. Methods 25: 402-408, 2001.

36. Xu YY, Guo M, Yang LQ, Zhou F, Yu C, Wang A, Pang TH, Wu HY, Zou XP, Zhang WJ, et al: Regulation of CD44v6 expression in gastric carcinoma by the IL-6/STAT3 signaling pathway and its clinical significance. Oncotarget 8: 45848-45861, 2017.

37. Zeng L, Zhen Y, Chen Y, Zou L, Zhang Y, Hu F, Feng J, Shen $J$ and Wei B: Naringin inhibits growth and induces apoptosis by a mechanism dependent on reduced activation of NF- $\kappa \mathrm{B} / \mathrm{COX}$-2-caspase-1 pathway in HeLa cervical cancer cells Int J Oncol 45: 1929-1936, 2014.

38. Xu W, Chen J, Lin J, Liu D, Mo L, Pan W, Feng J, Wu W and Zheng D: Exogenous $\mathrm{H} 2 \mathrm{~S}$ protects $\mathrm{H} 9 \mathrm{c} 2$ cardiac cells against high glucose-induced injury and inflammation by inhibiting the activation of the NF- $\mathrm{kB}$ and IL-1 $\beta$ pathways. Int J Mol Med 35: 177-186, 2015.

39. Coletta C, Papapetropoulos A, Erdelyi K, Olah G, Módis K, Panopoulos P, Asimakopoulou A, Gerö D, Sharina I, Martin E and Szabo C: Hydrogen sulfide and nitric oxide are mutually dependent in the regulation of angiogenesis and endothelium-dependent vasorelaxation. Proc Natl Acad Sci USA 109: 9161-9166, 2012.

40. Kimura H: Hydrogen sulfide: From brain to gut. Antioxid Redox Signal 12: 1111-1123, 2010

41. Huang X, Gao Y, Qin J and Lu S: The role of miR-34a in the hepatoprotective effect of hydrogen sulfide on ischemia/reperfusion injury in young and old rats. PLoS One 9: e113305, 2014.
42. You Q, Wu Z, Wu B, Liu C, Huang R, Yang L, Guo R, Wu K and Chen J: Naringin protects cardiomyocytes against hyperglycemia-induced injuries in vitro and in vivo. J Endocrinol 230: 197-214, 2016.

43. Tegeder I, Niederberger E, Israr E, Gühring H, Brune K, Euchenhofer C, Grösch S and Geisslinger G: Inhibition of NF-kappaB and AP-1 activation by R- and S-flurbiprofen. FASEB J 15: 2-4, 2001

44. Seo KW, Coh YR, Rebhun RB, Ahn JO, Han SM, Lee HW and Youn HY: Antitumor effects of celecoxib in COX-2 expressing and non-expressing canine melanoma cell lines. Res Vet Sci 96: 482-486, 2014

45. Wu X, Cai M, Ji F and Lou LM: The impact of COX-2 on invasion of osteosarcoma cell and its mechanism of regulation. Cancer Cell Int 14: 27, 2014.

46. Gao J, Tian J, Lv Y, Shi F, Kong F, Shi H and Zhao L: Leptin induces functional activation of cyclooxygenase-2 through JAK2/STAT3, MAPK/ERK and PI3K/AKT pathways in human endometrial cancer cells. Cancer Sci 100: 389-395, 2009.

47. Xu W, Chen GS, Shao Y, Li XL, Xu HC, Zhang H, Zhu GQ, Zhou YC, He XP and Sun WH: Gastrin acting on the cholecystokinin2 receptor induces cyclooxygenase-2 expression through JAK2/STAT3/PI3K/Akt pathway in human gastric cancer cells. Cancer Lett 332: 11-18, 2013.

48. Gong J, Xie J, Bedolla R, Rivas P, Chakravarthy D, Freeman JW, Reddick R, Kopetz S, Peterson A, Wang H, et al: Combined targeting of STAT3/NF- $\kappa \mathrm{B} / \mathrm{COX}-2 / \mathrm{EP} 4$ for effective management of pancreatic cancer. Clin Cancer Res 20: 1259-1273, 2014

49. Liu X, Ji Q, Ye N, Sui H, Zhou L, Zhu H, Fan Z, Cai J and $\mathrm{Li}$ Q: Berberine inhibits invasion and metastasis of colorectal cancer cells via COX-2/PGE2 mediated JAK2/STAT3 Signaling pathway. PLoS One 10: e0123478, 2015.

50. Xiong H, Du W, Sun TT, Lin YW, Wang JL, Hong J and Fang JY: A positive feedback loop between STAT3 and cyclooxygenase-2 gene may contribute to Helicobacter pylori-associated human gastric tumorigenesis. Int J Cancer 134: 2030-2040, 2014. 